\title{
Akciğer Kanseri Nedeniyle Ameliyat Olan Hastalarda Konfor Düzeyi ve Konforu Etkileyen Faktörler
}

\section{Comfort Level and Factor Affecting Comfort Level of Patients Who Had Surgery for Lung Cancer}

\author{
${ }^{1}$ Afide GÜNER, ${ }^{2}$ Azime KARAKOÇ KUMSAR \\ ${ }^{1}$ Istanbul Yedikule Göğüs Hastalıkları ve Göğüs Cerrahisi Eğitim ve Araştırma Hastanesi, İstanbul, Türkiye \\ ${ }^{2}$ Biruni Üniversitesi Sağlık Bilimleri Fakültesi Hemşirelik Bölümü, İstanbul, Türkiye
}

Afide Güner: https://orcid.org/0000-0002-3720-3069

Azime Karakoç Kumsar: https://orcid.org/0000-0001-6178-2147

\section{ÖZ}

Amaç: Araştırma akciğer kanseri nedeniyle ameliyat olan hastaların konfor düzeyi ile konforu etkileyen faktörleri belirlemek amaciyla yapıld 1 .

Materyal ve Metot: Tanımlayıcı ve kesitsel türdeki bu araştırma, bir kamu hastanesinde akciğer kanseri nedeniyle ameliyat olan 185 hasta ile yapıld1. Veriler hasta tanılama formu ve Perianestezi Konfor Ölçeği (PKÖ) kullanılarak elde edildi.

Bulgular: Hastaların ameliyat sonrası "Perianestezi Konfor Ölçeği” puan ortalaması $4,55 \pm 0,71$ olarak bulundu. Genel sağlık algısı iyi olan, şimdiki ameliyata yönelik tutumu olumlu olan ve ameliyat öncesi eğitim alan hastaların konfor puan ortalamalarının daha yüksek olduğ saptand $1(p<0,05)$. Konforu azaltan faktörler; hastaların kendilerini yabancı bir ortamda hissetmesi, çok endișeli olmaları, içinde bulundukları durumdan rahatsız olmaları ve ortam 1sisinın yeterli olmamasi olarak belirlendi.

Sonuç: Akciğer kanseri nedeniyle ameliyat olan hastaların ameliyat sonrası konfor düzeyinin yüksek seviyeye yakın olduğunu belirlendi. Ameliyat öncesi dönemde hemşirelerin, hastaların bireysel gereksinimlerine yönelik eğitimler vermesi ve cerrahi girișim sonrası hastaların konfor düzeyini belirleyerek, elde edilen sonuçlara göre bakımı bireysel olarak planlaması ve uygulanması önerilmektedir. Anahtar Kelimeler: Akciğer kanseri, göğüs cerrahisi, hemşirelik, konfor

\begin{abstract}
Objective: The study was performed to determine the comfort level and factor affecting comfort in patient undergoing surgery for lung cancer.

Materials and Methods: This descriptive and crosssectional study was conducted with 185 patient who had surgery for lung cancer, at a public hospital. The data were obtained by using patient identification form and Perianesthesia Comfort Questionnaire (PCQ).

Results: When postoperative period of patient were examined, Perianesthesia Comfort Questionnaire point avarange was found as $4.55 \pm 0.71$. The patient with good general health perception, positive attitude towards the current surgery and having preoperative training were found to have higer comfort score $(p<0.05)$. Factor reducing comfort were found that patients feel themselves in foreign enviroment and they have to be very worried. Also they are uncomfortable with the current situation and ambient temperature isn't enough.

Conclusion: The comfort level of the patient who had surgery for lung cancer was found to be high. It is suggested that nurses should be provided with planned trainings for individual needs in the perioperative period and that the comfort level is determined after the surgical intervention and the planning, implementation of the care according to the results obtained.
\end{abstract}

Keywords: Comfort, lung cancer, nursing, thoracic surgery

Yayın Bilgisi / Article Info:

Gönderi Tarihi/ Received: 03/07/2020

Kabul Tarihi/ Accepted: 16/03/202

Online Yayın Tarihi/ Published: 05/06/2021

Istanbul Yedikule Göğüs Hastalıkları ve Göğüs Cerrahisi Eğitim ve

Araştırma Hastanesi, İ́stanbul/ Türkiye

Tel: +905537010686

E-mail: afideguner@gmail.com 


\section{GÍRIŞ}

Akciğer kanseri tüm dünyada en sık görülen kanser türlerinden biridir ve sebep olduğu mortalite yükü açısından da oldukça önemli bir halk sağlığı sorunudur. Dünya Sağlık Örgütü (DSÖ) akciğer kanserinin 2018 y1lında toplam 2.093.876 yeni olgu ile tüm kanserlerin \%11,6'sını meydana getirdiğini bildirmiştir. Ayrıca akciğer kanseri tüm dünyada kansere bağlı ölümler içinde 1.76 milyon ölüm ile toplam kansere bağlı ölümlerin \%18,4'ünü oluşturmasıyla en yüksek orana sahiptir. ${ }^{1}$

Akciğer kanserlerinde uygulanacak tedavi yöntemi; tümör histolojisi, hastalığın evresi, pulmoner fonksiyonlar, komorbiditeler ve yaş gibi hastanın bireysel özellikleri doğrultusunda belirlenir. ${ }^{2}$ Akciğer kanserinde cerrahi tedavi en temel tedavi şekli olup; medikal olarak cerrahiye uygun evre I ve II akciğer kanserli hastalarda ana tedavi seçeneğidir. ${ }^{3}$

Akciğer rezeksiyon cerrahisi, hastaların aylarca fiziksel işleyişini azaltabilir, yaşam kalitelerini olumsuz yönde etkileyebilir ve farklı bir yaşam tarzı sürdürmek zorunda bırakabilir. Ayrıca, hastanın iyileşmesini engelleyebilecek postoperatif komplikasyon gelişme riski de yüksektir. ${ }^{4}$ Bütün cerrahi girişimler, bireyin hayatının doğrudan güvence altına almayı amaçlayan uygulamalar olmakla birlikte, bireyi tüm boyutları ile etkileyen bir travma olup, hastanın konforunun bozulmasina sebep olabilmektedir. ${ }^{5}$

Konfor, temel bir insan gereksinimidir ve bir sağlık sorunu ile karşılaşıldığında hastalar, bu temel bireysel gereksinimin sağlık profesyonelleri tarafından karşılanacağını ümit etmektedir. ${ }^{6}$ Hemşirelik felsefesi hastanın koruması, kollaması ve rahatlatması üzerine temellenmiştir ve önemli sorumluluk alanlarından birisi de hasta konforunun sağlanması ve sürdürülmesidir. ${ }^{7} \mathrm{Bu}$ nedenle; hastanın konfor düzeyini yükseltmek, hemşirelere karşı güven ve memnuniyeti arttırmak için sağlık bakımı sunan merkezlerde, fiziksel ve sosyal yönden rahatlığın sağlanması gerekmektedir. ${ }^{8}$

"Fiziksel, psikospirituel, çevresel ve sosyo-kültürel boyutlarda ferahlama, rahatlama ve sorunların üstesinden gelme" olarak tanımlanan konfor, bütün cerrahi girişimlerde olduğu gibi göğüs cerrahisi sonrasında da olumsuz yönde etkilenmektedir. ${ }^{9}$

$\mathrm{Bu}$ bağlamda, araştırma akciğer kanseri tanısıyla ameliyat olan hastaların konfor düzeyleri ile konforu etkileyen faktörleri belirlemek amacıyla planlandı. Elde edilen sonuçların, hemşirelik bakımını planlamak ve bakım kalitesini geliştirmek için geliştirile- cek stratejiler açısından hemşirelere ve literatüre kaynak sağlanacağı düşünülmektedir.

\section{MATERYAL VE METOT}

Araştırmanın Etik Boyutu: Helsinki Deklarasyonu Prensipleri'ne uygun davranilarak; verileri toplamadan önce bir üniversitenin etik kurulundan (Tarih: 25.02.2019, karar no: 2019/26-36) ve araştırmanın yapıldığ 1 kurumun bilimsel kurulundan (Tarih: 19.06.2019, karar no: 223-4) yazılı izin alındı. Araştırmada kullanılan Perianastezi Konfor Ölçeği'nin araştırmamızda kullanılması için, ölçeğin Türkçe geçerlilik ve güvenirliğini yapan araştırmacıdan mail yolu ile izin alındı. Araştırmamızda veri toplama aşamasında hastalara araştırmanın amacı sözlü ve yazılı olarak aktarılmış ve yazılı onamları alındı.

Araştırmanın Amacı ve Tipi: Araştırma, akciğer kanseri nedeniyle ameliyat olan hastaların konfor düzeyleri ile konforu etkileyen faktörleri belirlemek amacıyla tanımlayıcı ve kesitsel tipte gerçekleştirildi.

Araştırmanın Evren ve Örneklemi: Araştırmanın evrenini, İstanbul'da bir kamu hastanesinde HaziranEylül 2019 tarihleri arasında akciğer kanseri nedeniyle ameliyat olan ve yatarak tedavi gören 350 hasta oluşturdu. Araştırmanın örneklem büyüklüğü, bilinen örnekleme yöntemi kullanılarak $\left(\mathrm{Nt}^{2} \mathrm{pq} / \mathrm{d}^{2}(\mathrm{~N}\right.$ $-1)+\mathrm{t}^{2} \mathrm{pq}$ ) minimum 183 olarak hesapland..$^{10}$ Akciğer kanseri tanısı ile ameliyat olarak yatarak tedavi gören, 18 yaş ve üzeri olan, bilinci açık, iletişim kurabilen ve çalışmaya katılmayı kabul eden bireyler çalışma kapsamına alındı. Böylece, araştırmaya dahil edilme kriterlerine uyan 185 hasta ile çalışma tamamlanmış oldu.

Veri Toplama Araçlart: Veriler hasta tanılama formu ve Peranestezi Konfor Ölçeği kullanılarak toplandı. Araştırmacılar tarafından literatür bilgisinden yararlanılarak hazırlanmış olan hasta tanılama for$\mathrm{mu}$; hastaların bireysel özelliklerini ve hastalık özelliklerini sorgulayan 36 sorudan oluşmaktadır. ${ }^{11,12}$

Perianestezi Konfor Ölçeği (PKÖ): Kolcaba tarafından geliştirilmiş olup konfor gereksinimlerinin saptanması ve beklenen konforda artma sonucuna ulaşma durumunun değerlendirilmesi amacıyla kullanılmaktadır. Ölçeğin Türkçe geçerlik ve güvenirlik çalışmasını Üstündağ ve Aslan gerçekleştirmiş ve Cronbach's alfa katsayısı 0,83 olarak hesaplanmıştır. ${ }^{5}$ Ölçek, hastanın ameliyat öncesi ve sonrası genel düşünce sürecini yansıtan kendini anlama ve duygularını sorgulayan 24 maddeden oluşmaktadır. Ölçekteki her bir madde "kesinlikle katılmıyorum" ifade- 
sinden, "kesinlikle katıliyorum" ifadesine doğru 1 ve 6 arasında değişen puanlama sistemine sahiptir. Ölçekten alınabilecek, en yüksek toplam puan 144, en düşük toplam puan 24'tür. Elde edilen toplam puan ölçek madde sayısına bölünür ve ortalama değer 1 6 aralığında hesaplanır. Düşük puan konfor seviyesinin düşük, yüksek puan ise konfor seviyesinin iyi olduğunu göstermektedir. ${ }^{5}$

Verilerin Değerlendirilmesi: Veriler, SPSS 22.0 paket programında yorumlandı. Araştırmada elde edilen veriler SPSS (Statistical Package for Social Sciences) for Windows 22.0 programı kullanılarak analiz edildi. Konfor puanının normal dağılım gösterdiği Kolmogorov-Smirnov normal dağılım testi yapılarak saptand $(p=1,133>0,05)$. Verilerin analizlerinde parametrik yöntemler uygulandı. Verilerin değerlendirilmesinde ortalama ve yüzdelik dağılıma ek olarak t-testi, Tek yönlü Anova testi, Scheffe testi ve Pearson korelasyon analizi kullanıldı. İstatistiksel değerlendirmede anlamlılık $\mathrm{p}<0,05$ olarak kabul edildi.

\section{BULGULAR}

Çalışmaya katılan bireylerin yaş ortalamaları $58,87 \pm 12,01$ y1l olup; \%41,1'i 61-70 yaş aralığındadır. Hastaların \%70,3'ünün erkek, \%91,4'ünün evli, $\% 70,8$ 'inin eğitim durumunun ortaokul ve altı olduğu, \%47'sinde hekim tarafından tanı konmuş bir kronik hastalığı olduğu belirlendi. Hastaların genel sağlık düzeyi algılarının, \%65,9'unun iyi olduğu, \% $68,6^{\prime}$ 'sının geçirilmiş ameliyat öyküsü olduğu, önceki cerrahi deneyim algısının \%50,4'ünün iyi olduğu, \%58,9'unun şimdiki ameliyata yönelik tutumunun olumlu olduğu, \%81,1'i ameliyat öncesi eğitim ald1ğı, \%53,5'ine lobektomi yapıldığı saptandı (Tablo 1).

Hastaların konfor puan ortalamaları ile yaş, cinsiyet, medeni durum, eğitim durumu, kronik hastalık durumu, geçirilmiş ameliyat öyküsü, önceki cerrahi deneyim ve yapılan ameliyat değişkenlerine göre anlamlı fark saptanmadı $(\mathrm{p}>0,05)$. Genel sağlık algısı iyi olanların konfor puan ortalamaları alg1sı orta ve kötü yönde olanların konfor puan ortalamalarından istatistiksel olarak anlamlı düzeyde yüksek bulundu $(\mathrm{t}=1,974 ; \mathrm{p}=0,05<0,05)$, ( Tablo 1).

Hastaların konfor puan ortalamaları şimdiki ameliyata yönelik tutum değişkenine göre anlamlı fark gösterdi $(\mathrm{F}=5,599 ; \mathrm{p}=0,004<0,05)$. Farkın nedeni, şimdiki ameliyata yönelik tutum olumlu olanların konfor puan ortalamalarının şimdiki ameliyata yönelik tutum olumsuz olanların konfor puan ortalamalarından yüksek olması olarak belirlendi $(p<0,05)$.
Ameliyat öncesi eğitim alanların konfor puanları ortalamaları, ameliyat öncesi eğitim almayanların konfor puan ortalamalarında anlamlı düzeyde yüksek bulundu ( $\mathrm{t}=2,591 ; \mathrm{p}=0,01<0,05)$, ( Tablo 1$)$.

Hastaların ameliyat sonrası 'Perianestezi Konfor Ölçeği' puan ortalaması Tablo 2'de görüldüğü gibi 4,55 $\pm 0,71$ olarak saptandi. Hastaların konforunu arttıran maddelerin; en yüksek ortalamadan başlayarak sırasıyla "ailem/arkadaşlarım bu durumun üstesinden gelmemde yardımcı oldu", "hemşire benimle çok ilgilendi", "bana uygulanan bakım kendimi güvende hissetmemi sağladı", "burada aldığım bakımdan memnunum", "buradaki ortamın güvenli olduğunu hissettim" olduğu saptandı. Hastaların konforunu azaltan maddelerin; en az ortalamadan başlamak üzere sırasıyla "yabancı bir ortamdı", “çok endişeliydim", "içinde bulunduğum durumdan rahatsızdım", "ilaç uygulanan/serum verilen bölge ağr1lıydı" "üşüyordum” olduğu saptandı (Tablo 2).

\section{TARTIŞMA VE SONUÇ}

Konfor temel insan ihtiyaçların bir bileşenidir ve insanlarda doğdukları andan itibaren bir konfor beklentisi vardır. Özellikle postoperatif dönemde hastalar için önemli olan kavramlardan birisidir. Konfor dikkate alınarak sürdürülen tedavi ve bakım anlayışı, daha iyi sağlık bakım sonuçlarına ulaşılabilmede önemli bir belirleyici olabilmektedir. ${ }^{4}$ Çalışmada, akciğer kanserli hastalarda ameliyat sonrası konfor düzeyleri ve konforu etkileyen faktörler incelenmiş ve elde edilen bulgular literatür doğrultusunda tart1şılmıştır.

Hastaların ameliyat sonrası 'Perianestezi Konfor Ölçeği' toplam puan ortalaması $4,55 \pm 0,71$ olarak saptand1. Bu bulgu, hastaların konfor düzeyinin yükseğe yakın olduğunu göstermektedir. Perianestezi konfor ölçeği puan ortalaması kalp ameliyatı olan hasta grupları ile yürütülen çalışmada, 5,06 olarak belirlenmiştir. ${ }^{9}$ Göğüs cerrahisi geçiren hastalarla yürütülmüş benzer bir çalışmada ise, ölçek puanı ortalamanın üstünde tespit edilmiştir. ${ }^{6}$

Hasta memnuniyeti sağlık kurumlarında hizmet kalitesini belirlemede temel bir kriterdir. Hasta konforunu arttırmada en kilit personel hemşirelerdir. Hemşireler 24 saat hastayla birlikte olduklarından konfor durumunu arttırmada ve hasta memnuniyetin belirlenmesinde en temel öğedir. ${ }^{12}$ Çalışmada, hastalar doktor ve hemşirelerin kendilerine karşı ilgili olduklarını, uygulanan bakımın kendilerini güvende hissetmelerini sağladığını ve aldıkları bakımdan memnun olduklarını ifade etmişlerdir. Hastaların konfor düzeylerinin aldıkları bireysel bakım ve destek ile 
arttığı düşünülmektedir.

Çalışmada, hastaların kendilerini yabancı bir ortamda hissettiği, çok endişeli oldukları, içinde bulundukları durumdan rahatsız oldukları, ilaç uygulanan/ serum verilen bölgenin ağrılı olduğunu düşündükleri, ortam ısısının yeterli olmadığı ve üşüdükleri belirlendi. Bu durumların hasta konforunun azalmasına yol açtı̆̆ görülmektedir.

Hastaların alıştığı çevreden ayrılarak, yabancı görünen ameliyathane ortamına girerken endişe yaşamaya başladıkları belirtmiştir. ${ }^{13}$ Ameliyat öncesi bireylerin \%62,13'ünün yapılacak cerrahi operasyona bağlı endişe yaşadıkları ve \%21,58'inin ameliyathaneyi korkunç bir yer olarak hatırladıkları belirlenmiştir. ${ }^{14}$ Yapılan diğer çalışmalarda da cerrahi girişim öncesi hastaların anksiyete deneyiminin yüksek olduğu belirtilmektedir. ${ }^{15,16}$

Yapılan çalışmalarda ameliyathanede üşüyen hasta oranının $\% 33,98$ olduğ $^{14}$ ve hastalarda $\% 63,8$ oranında üşüme ve titreme meydana geldiği belirlenmiştir. $^{2}$ Postoperatif erken dönemde hastalarda hipotermi sık rastlanan bir durum olup; bu dönemde hastaların 1sınması ve vücut sicaklığının normoterapiye dönmesi hastayı rahatlatmaktadır. ${ }^{17,18}$ Hastalar anestezinin etkisinin geçmesiyle beraber ayılma odası ve yoğun bakımda yaşadıkları olayları hatırlamakta ve bu alanlarda üşüdükleri belirtmektedirler. Bu alanlarda ortam sıcaklığı yükseltilemese bile hastanın ısınması için gerekli girişimlerin planlanması gerekmektedir.

Çalışmada, medeni durumun konfor puanına etkisi açısından evli ve bekar hastaların konfor puan ortalamaları arasında anlamlı fark saptanmadı. Benzer çalışmalar incelendiğinde, evli ya da bekar olmanın konfor üzerinde etkisi olmadığı belirlenen çalışmaya $\mathrm{da}^{11}$, tek başına olan hastalarda konfor düzeyinin evli hastalardan daha düşük olduğu belirlenen çalışmaya $\mathrm{da}^{19}$ rastlanmaktadır. Literatürde bu durum, ailenin sosyal desteğini kaybetmesi sonucu cerrahi girişimin konforu olumsuz etkileyen sorunları şiddetlendirdiği ifade edilmektedir. ${ }^{19}$

Çalışmada, hastaların büyük bir çoğunluğu evliydi ve ailelerinden destek alanların konfor puan ortalamalarının yüksek olduğu saptandı. Bu durum hastaların konforunun sağlanmasında sosyal desteğin ne kadar etkili olduğunu göstermektedir.

Hastaların eğitim durumuna göre dağılımı incelendiğinde; katılımcıların eğitim durumunun konfor düzeyini etkilemediği bulundu. Ancak, yapılan benzer çalışmalarda, eğitim düzeyi arttıkça konfor düzeyinin de arttığ belirlenmiştir. $^{9-19}$ Hastaların eğitim seviyesi direk olarak konforu etkilemese bile verilen hemşirelik eğitimlerinin anlaşılması açısından dolay1 olarak etkisinin olduğunu düşünülebilir. Belirli bir eğitim düzeyine sahip hastalar kendi bakımını planlamada ve uygulamada aktif rol alabilmektedir.

Çalışmada, hastaların genel sağlık düzeyi algılarının \%65,9 oranında iyi olduğu ve genel sağlık algısı iyi olanların konfor düzeyi ölçek puan ortalamalarının, genel sağlık algılarını orta ve kötü olarak belirten hastalardan daha yüksek bulundu. Çalışmadan elde edilen bu bulgu, hastaların sağlık algılarının yüksek tutulmasının konfor düzeylerini olumlu yönde etkileyebileceğini göstermektedir.

Çalışmaya katılan hastaların, şimdiki ameliyatına yönelik tutumu olumlu olanların konfor düzeyinin, şimdiki ameliyatına yönelik tutumu olumsuz olanlardan yüksek olduğu saptandı. Benzer bir çalışmada da hastaların \%86,2'inin şimdiki ameliyata yönelik tutumunun iyi olduğunu ve bu durumun konfor düzeylerini olumlu yönde etkilediğini göstermektedir. ${ }^{12}$ $\mathrm{Bu}$ bulguya dayanarak, hastaların ameliyata yönelik tutumlarının değerlendirilmesi ve olumsuz düşüncelerin giderilmesi yönünde uygulanacak girişimlerin, hastaların ameliyat sonrası konfor düzeyini yükseltebileceği söylenebilir.

Yapılan çalışmalarda, cerrahi girişim öncesi verilen eğitimin hastaların tedaviye uyumunu ve memnuniyet düzeyini arttırdığı belirlenmiştir. Ayrıca, hastaların cerrahi girişim sonrası fizyolojik ve psikolojik iyileşmelerinde, bağımsız rol ve fonksiyonlarında da artış sağlanmış ve anksiyete, ameliyat sonrası komplikasyon oranı, hastanede kalış süresinde azalma olduğu belirlenmiştir. ${ }^{20-22}$ Çalışmada, ameliyat öncesi eğitim alanların konfor düzeyi ölçek puan ortalamaları, ameliyat öncesi eğitim almayanlarınkinden yüksek saptandı. Aynı şekilde benzer çalışmalarda da, ameliyattan önce verilen eğitimin hasta konforu üzerinde olumlu etkisi bulunmuştur. ${ }^{11,23,24}$ Ameliyat öncesi bilgilendirmenin akciğer kanseri nedeniyle ameliyat olan hastaların konfor düzeyinin ve alınan hemşirelik bakım memnuniyetin artmasına etki ettiği görülmektedir. Doğru zaman ve doğru bir içerikle bireysel ihtiyaçlar doğrultusunda verilen etkin sağlık eğitimleri ile konfor düzeyi artırılabilir. Sonuç olarak, çalışmada elde edilen bulgular doğrultusunda, akciğer kanseri nedeniyle ameliyat olan hastaların ameliyat sonrası konfor düzeyinin yüksek olduğunu belirlendi. Genel sağlık algısı iyi olan, şimdiki ameliyata yönelik tutum olumlu olan, ameliyat öncesi eğitim alan hastaların konfor puan ortalamalarının daha yüksek olduğu saptandı. Araştırma bulguları, bir kamu hastanesinde akciğer kanseri nedeniyle ameliyat olan ve yatarak tedavi gören has- 
talardan elde edilen veriler ile sınırlıdır. Araştırmada hastaların konfor düzeyi, kullanılan ölçeğin ölçtüğü değerlerle sınırlıdır. Bunlar bu araştırmanın sınırlılıklarını oluşturmaktadır.

Etik Komite Onayı: Helsinki Deklarasyonu Prensipleri'ne uygun davranılarak; verileri toplamadan önce Biruni Üniversitesi Girişimsel Olmayan Klinik Araştırmalar Etik kurulundan (Tarih: 25.02.2019, karar no: 2019/26-36) ve araştırmanın yapıldığ 1 Yedikule Göğüs Hastalıkları ve Göğüs Cerrahisi Eğitim Araştırma Hastanesi Bilimsel Kurulundan (Tarih: 19.06.2019, karar no: 223-4) yazılı izin alınmiştır.

Çıkar Çatışması: Yazarlar çıkar çatışması bildirmemektedir.

Yazar Katkllarl: Fikir- AG; Tasarım- AG, AKK; Denetleme - AG, AKK; Kaynaklar - AG, AKK; Malzemeler - AG, AKK; Veri Toplanması ve/veya İşlemes- AG; Analiz ve/veya Yorum- AG, AKK; Literatür Taraması- AG, AKK; Yazıyı Yazan - AG; Eleştirel İnceleme- AG, AKK.

Hakem değerlendirmesi: Dış bağımsız.

Diğer: Bu yazı 11-14 Mart 2020 tarihleri arasında Antalya'da düzenlenen Ulusal Akciğer Sağlığ 1 Kongresi'nde sözel bildirim olarak sunulmuş ve kongre kitabında özet bildiri olarak yayınlanmıştır. Yüksek lisans tezidir.

\section{KAYNAKLAR}

1. World Health Organization. International Agency For Research On Cancer 2018. http://gco.iarc.fr/ today/data/factsheets/cancers/15-Lung-factsheet.pdf. Erişim tarihi 21 Eylül 2019.

2. Yılmaz E, Çeçen D, Toğaç HK, Mutlu S, Aslan A. Ameliyat sürecindeki hastaların konfor düzeyleri ve hemşirelik bakımları. Celal Bayar Üniversitesi Sağlık Bilimleri Enstitüsü Dergisi. 2018;5 (1):3-9.

3. Bayram AS. Akciğer kanserinde ameliyat edilecek hastanın seçimi ve güncel cerrahi yaklaşımlar. Türk Radyoloji Derneği Semineri. 2014;2:378-384.

4. Handy Jr JR, Asaph JW, Skokan L, Reed CE, Koh S. What happens to patients undergoing lung cancer surgery?: Outcomes and quality of life before and after surgery. Chest. 2002;122 (1):21-30.

5. Üstündağ H, Aslan FE. The Turkish adaptation of perianesthesia comfort questionnaire. Turkiye Klinikleri Journal of Nursing Sciences. 2010;2 (2):94-99.
6. Ören B. Göğüs cerrahisi uygulanan hastaların konfor ve anksiyete düzeyini etkileyen faktörler. Sağlık Bilimleri ve Meslekleri Dergisi. 2018;5(3):324-332.

7. Tuti Nuraini SKp M, Dewi Gayatri SKp M. Comfort assessment of cancer patient in palliative care: a nursing perspective. International Journal of Caring Sciences. 2017;10(1):209.

8. Şahin PB, Rızalar S. Ameliyat geçiren hastalarda konfor düzeyi ve etkileyen faktörlerin incelenmesi. Sağlık Bilimleri ve Meslekleri Dergisi. 2018;5(3):404-413.

9. Üstündağ H. Koroner arter bypass greft cerrahisi uygulanan hastaların konfor düzeyi. Marmara Üniversitesi Sağlık Bilimleri Enstitüsü Cerrahi Hastalıkları Hemşireliği Anabilim Dalı, Doktora Tezi. İstanbul, Türkiye. 2009.

10.Trost JE. Statistically nonrepresentative stratified sampling: A sampling technique for qualitative studies. Qualitative sociology. 1986;9(1):54-57.

11.Sönmez A. Koroner arter bypass greft ameliyat1 uygulanan hastaların konfor ve kaygı deneyimlerinin değerlendirilmesi. Trakya Üniversitesi Sağlık Bilimleri Enstitüsü Hemşirelik Anabilim Dalı, Yüksek Lisans Tezi. Edirne, Türkiye. 2013.

12. Şahin PB. Ameliyat geçiren hastalarda konfor düzeyi ve etkileyen faktörlerin incelenmesi. İstanbul Medipol Üniversitesi Sağlık Bilimleri Enstitüsü Hemşirelik Anabilim Dalı, Yüksek Lisans Tezi. İstanbul, Türkiye. 2016.

13. Erdil F, Elbaş NÖ, Bayraktar N, Çelik SŞ. Hasta yakınlarının ameliyat öncesi döneme ilişkin bilgi gereksinimleri, ameliyatı beklerken yaşadıkları duyguları ve ameliyathane bekleme salonuna ilişkin görüşleri. Hemşirelik Forumu Dergisi. 2000;3(6):1-5.

14. Özbayır T, Demir F, Candan Y, Coşkun İ, Dramalı A. Hastaların perioperatif döneme ilişkin izlenimlerinin incelenmesi. Anadolu Hemşirelik ve Sağlık Bilimleri Dergisi. 2003;6(1):14-23.

15. Oflaz F, Vural H. Yatan hastaların anksiyete ve depresyon düzeyleri ve ilişkili faktörlerin incelenmesi. SDÜ Tıp Fakültesi Dergisi. 2010;17 (1):1-7.

16. Arslan S, Taylan S, Deniz S. Nöroşirürji hastalarinin ameliyat öncesi anksiyete düzeyleri. Anadolu Hemşirelik ve Sağlık Bilimleri Dergisi. 2017;20(1):17-21.

17. Girard NJ. Clients having surgery: Promoting positive outcomes. Medical surgical nursing clinical management for positive outcomes. Philadelphia: Saunders Elsevier. 2009:193-194. 
18. Rasmussen BS, Sollid J, Rees SE, Kjaergaard S, Murley D. Oxygenation within the first $120 \mathrm{~h}$ following coronary artery bypass grafting. Influence of systemic hypothermia $\left(32^{\circ} \mathrm{C}\right)$ or normothermia $\left(36^{\circ} \mathrm{C}\right)$ during the cardiopulmonary bypass: a randomized clinical trial. Acta Anaesthesiologica Scandinavica. 2006;50(1):64-71.

19. Seyedfatemi N, Rafii F, Rezaei M, Kolcaba K. Comfort and hope in the preanesthesia stage in patients undergoing surgery. Journal of PeriAnesthesia Nursing. 2014;29(3): 213-220.

20. Yılmaz M. Ameliyat öncesi öğretimin ameliyat sonras1 komplikasyonlara ve hasta memnuniyetine etkisi. Hemşirelik Araştırma Dergisi 2002;4(1):40-51.

21. Johansson K, Nuutila L, Virtanen H, Katajisto J, Salanterä S. Preoperative education for orthopaedic patients: systematic review. Journal of Advanced Nursing. 2005;50(2):212-223.

22. Yavuz M. Ameliyat Öncesi Bakım. Karadakovan A, Eti Aslan F (eds.), Adana: Nobel Tip Kitapevi; 2010:293-299.

23. Gürçayır D. Kalça protezi ameliyatı olacak hastalara verilen eğitimin ameliyat sonrası konfor düzeyi ve günlük yaşam aktivitelerine etkisi. Atatürk Üniversitesi Sağlık Bilimleri Enstitüsü Cerrahi Hastalıkları Hemşireliği Anabilim Dalı, Yüksek Lisans Tezi. Erzurum, Türkiye. 2011.

24. Amaç HY, Çam R. Günübirlik cerrahide hasta konforu ve hasta konforunu etkileyen etmenler. Adıyaman Üniversitesi Sağlık Bilimleri Dergisi. 2019;5(1):1222-1237. 
Tablo 1. Hastaların tanıtıcı özellikleri ve ameliyat sürecine ilişkin özellikleri ile Perianestezi Konfor Ölçeği arasındaki ilişkinin değerlendirilmesi $(\mathrm{N}=185)$.

\begin{tabular}{|c|c|c|c|c|}
\hline Demografik Özellikler & $\mathbf{N}$ & $\%$ & $\begin{array}{c}\text { PKÖ } \\
\text { (Ortalama } \pm \text { Standart } \\
\text { Sapma) }\end{array}$ & İstatiksel Analiz \\
\hline \multicolumn{5}{|l|}{ Yaş } \\
\hline 50 Ve Alt1 & 38 & 20,5 & $4,624 \pm 0,690$ & \multirow{4}{*}{$\begin{array}{l}\mathrm{F}=2,197 \\
\mathrm{p}=0,090\end{array}$} \\
\hline $51-60$ & 49 & 26,5 & $4,652 \pm 0,739$ & \\
\hline $61-70$ & 76 & 41,1 & $4,560 \pm 0,631$ & \\
\hline 71 Ve Üzeri & 22 & 11,9 & $4,206 \pm 0,910$ & \\
\hline \multicolumn{5}{|l|}{ Cinsiyet } \\
\hline Kadın & 55 & 29,7 & $4,474 \pm 0,770$ & \multirow{2}{*}{$\begin{array}{c}\mathrm{t}=-1,005 \\
\mathrm{p}=0,316\end{array}$} \\
\hline Erkek & 130 & 70,3 & $4,590 \pm 0,693$ & \\
\hline \multicolumn{5}{|l|}{ Medeni Durum } \\
\hline Evli & 169 & 91,4 & $4,551 \pm 0,693$ & \multirow{2}{*}{$\begin{array}{l}\mathrm{t}=-0,313 \\
\mathrm{p}=0,754\end{array}$} \\
\hline Bekar & 16 & 8,6 & $4,609 \pm 0,953$ & \\
\hline \multicolumn{5}{|l|}{ Eğitim Durumu } \\
\hline Ortaokul Ve Alt1 & 131 & 70,8 & $4,503 \pm 0,718$ & \multirow{3}{*}{$\begin{array}{l}F=1,938 \\
p=0,147\end{array}$} \\
\hline Lise & 34 & 18,4 & $4,597 \pm 0,616$ & \\
\hline Yükseköğretim & 20 & 10,8 & $4,833 \pm 0,826$ & \\
\hline \multicolumn{5}{|l|}{ Kronik Hastalık Durumu } \\
\hline Var & 87 & 47,0 & $4,560 \pm 0,661$ & \multirow{2}{*}{$\begin{array}{l}\mathrm{t}=0,076 \\
\mathrm{p}=0,940\end{array}$} \\
\hline Yok & 98 & 53,0 & $4,552 \pm 0,766$ & \\
\hline \multicolumn{5}{|l|}{ Genel Sağlık Algısı } \\
\hline İyi & 122 & 65,9 & $4,630 \pm 0,744$ & \multirow{2}{*}{$\begin{array}{c}t=1,974 \\
p=0,050 *\end{array}$} \\
\hline Orta ve Kötü & 63 & 34,1 & $4,412 \pm 0,640$ & \\
\hline \multicolumn{5}{|c|}{ Geçirilmiş Ameliyat Öyküsü } \\
\hline Var & 127 & 68,6 & $4,547 \pm 0,708$ & \multirow{2}{*}{$\begin{array}{l}\mathrm{t}=-0,244 \\
\mathrm{p}=0,807\end{array}$} \\
\hline Yok & 58 & 31,4 & $4,575 \pm 0,740$ & \\
\hline \multicolumn{5}{|l|}{ Önceki Cerrahi Deneyim } \\
\hline İyi & 64 & 50,4 & $4,589 \pm 0,716$ & \multirow{3}{*}{$\begin{array}{l}\mathrm{F}=0,711 \\
\mathrm{p}=0,493\end{array}$} \\
\hline Orta & 43 & 33,9 & $4,565 \pm 0,719$ & \\
\hline Kötü & 20 & 15,7 & $4,375 \pm 0,667$ & \\
\hline \multicolumn{5}{|c|}{ Şimdiki Ameliyata Yönelik Tutum } \\
\hline Olumlu & 109 & 58,9 & $4,699 \pm 0,671$ & \multirow{3}{*}{$\begin{array}{c}\mathbf{F}=5,599 \\
p=0,004 * \\
\text { PostHoc=1 } \% 2,1>3 \\
(p<0,05)\end{array}$} \\
\hline Olumsuz & 45 & 24,3 & $4,342 \pm 0,822$ & \\
\hline Kararsızım & 31 & 16,8 & $4,362 \pm 0,593$ & \\
\hline \multicolumn{5}{|c|}{ Ameliyat Öncesi Eğitim Alma Durumu } \\
\hline Eğitim Almış & 150 & 81,1 & $4,621 \pm 0,683$ & \multirow{2}{*}{$\begin{array}{c}\mathrm{t}=\mathbf{2 , 5 9 1} \\
\mathbf{p}=\mathbf{0 , 0 1 0} *\end{array}$} \\
\hline Eğitim Almamış & 35 & 18,9 & $4,277 \pm 0,796$ & \\
\hline \multicolumn{5}{|l|}{ Yapılan Ameliyat } \\
\hline Pnömonektomi & 29 & 15,7 & $4,578 \pm 0,633$ & \multirow{4}{*}{$\begin{array}{l}F=0,092 \\
p=0,964\end{array}$} \\
\hline Lobektomi & 99 & 53,5 & $4,564 \pm 0,737$ & \\
\hline Wedge Rezeksiyonu & 44 & 23,8 & $4,509 \pm 0,739$ & \\
\hline Bilobektomi & 13 & 7,0 & $4,599 \pm 0,727$ & \\
\hline
\end{tabular}

t: Student-t Testi; F: Tek Yönlü ANOVA Testi; Post-Hoc: Scheffe Testi p $<0,05$. 
Tablo 2. Hastaların Perianestezi Konfor Ölçeğine ilişkin bulgular (N=185).

\begin{tabular}{|l|c|c|}
\hline Maddeler & Ortalama & $\begin{array}{c}\text { Standart } \\
\text { Sapma }\end{array}$ \\
\hline Sakindim & 4,86 & 1,36 \\
\hline Üşüyordum & 3,89 & 2,05 \\
\hline Yabancı Bir Ortamdı & 2,76 & 1,84 \\
\hline İçinde Bulunduğum Durumdan Rahatsızdım & 3,63 & 2,06 \\
\hline Ailem/arkadaşlarım Bu Durumun Üstesinden Gelmemde Yardımcı Oldu & 5,56 & 0,91 \\
\hline Ameliyattan Önce Anestezi Uzmanı İle Konuşma Fırsatım Oldu & 4,86 & 1,67 \\
\hline Mahremiyetime Saygı Gösterilmedi & 4,68 & 1,88 \\
\hline Çok Endişeliydim & 3,52 & 1,95 \\
\hline Hemşirem Duygularımı Önemsemedi & 4,50 & 1,89 \\
\hline Gürültü Rahatsız Ediciydi & 4,36 & 1,98 \\
\hline Hemşirem Nazikti & 5,02 & 1,30 \\
\hline Anesteziye İlişkin Daha Çok Bilgiye Gereksinimim Vardı & 3,96 & 2,09 \\
\hline Kontrolümü Kaybettim & 5,05 & 1,62 \\
\hline Çevremdeki Genel Hava Güven Vericiydi & 4,85 & 1,28 \\
\hline Bakım Kalitem Yetersizdi & 4,18 & 1,94 \\
\hline İsteklerim Yerine Getirildi & 5,11 & 1,36 \\
\hline Öz-Saygım Korunmadı & 5,00 & 1,61 \\
\hline Hızlı Bir İyileşme Süreci Öngörebiliyordum & 4,61 & 1,28 \\
\hline Buradaki Ortamın Güvenli Olduğunu Hissettim & 5,13 & 1,04 \\
\hline Bana Uygulanan Bakım Kendimi Güvende Hissetmemi Sağladı & 5,20 & 1,00 \\
\hline Uyumaktan Korkmuyordum & 4,27 & 2,08 \\
\hline İlaç Uygulanan/serum Verilen Bölge Ağrılıydı & 3,85 & 1,98 \\
\hline Burada Aldığım Bakımdan Memnunum & 5,15 & 0,99 \\
\hline Hemşire Benimle Çok İlgilendi & 5,22 & 0,94 \\
\hline Genel & $\mathbf{4 , 5 5}$ & $\mathbf{0 , 7 1}$ \\
\hline
\end{tabular}

